Chronic Tomboys: Feminism, Survival, and Paranoia in Jodie Foster's Body of Work

Lynne Stahl 


\title{
Chronic Tomboys: Feminism, Survival, and Paranoia in Jodie Foster's Body of Work
}

\author{
by Lynne Stahl
}

\begin{abstract}
From Freaky Friday (1976) to Flightplan (2005), Jodie Foster has made a career of defying gender norms-a defiance predicated largely upon her characteristically tomboyish embodiment and a mode of being that combines activeness, visual agency, and a distinctively resistant demeanor that spans her body of work to the extent that one can hardly watch any one of her films without involuntary recourse to her earlier and later movies. This essay takes up David Fincher's Panic Room (2002), which unites tomboy figures of two generations in Foster and Kristen Stewart and works, in light of the former's corpus and its feminist bent, to refuse the trope that sees tomboyism capitulate to heteronormative strictures in adolescence. Instead, Panic Room reproduces that embodied resistance in an adult through interactions with her daughter. The essay then proceeds further into the films of an iconic tomboy actress to posit a mode of queer feminist reproductivity enacted through Foster's star image and a recuperation of feminist "paranoia" through the consistent critique of heteronormativity that her aggregate body of work performs. Moreover, it addresses debates within queer theory about time, refuting antisocial currents - the push against "for-the-child" sentiments predominant in contemporary political rhetoric - and proposing an alternative, recursive temporality, and within the field of feminist film studies, demonstrating a subversive potential within commercial narrative film across the span of one Hollywood star's career.
\end{abstract}

In David Slade's Hard Candy (2005), Ellen Page plays Hayley, a tomboyish fourteen-year-old who entraps and torments a sexual predator. She outlines the bleak legal scenario the latter faces with relish, ruminating on its suitability to cinematic adaptation and to one Hollywood star in particular: "Jodie Foster directs the movie version of the whole thing." This glib reference, from one notable tomboy actress about perhaps the most iconic of all, locates Foster's oeuvre, film convention, and the Hollywood industry itself at the heart of issues of eroticized childhood, feminist transgression, and sexualized violence. At the same time, its citation of Foster as 
director rather than actor is surprising: in 2005 her directing credits consisted solely in Little Man Tate (1991), Home for the Holidays (1995), and a single episode of Tales from the Dark Side (1988). The curious transposition the reference effects between Foster's acting career and relatively humble directing résumé suggests that her embodied resistance to heterosexist norms in fact carries beyond her acting and registers with her audiences as part of a more imminently authorial position. It is from this integrative view of Foster as agent rather than simply actress that, this essay contends, the queer and feminist impact of her work provenes. Hard Candy's debt to Foster thus resides not only in the plotline so common to her films--seemingly outmatched young female draws on wits, grit, and calculated performances of gender to battle normalized sexist forces that exist as much in the sociocultural institutions that comprise the world of the film as in the villains themselves--but also in Foster's characteristic mode of inhabiting these roles, which devolves from her star persona and the trajectory of her career over the past forty years. Building from the conceptions of agential celebrity, vested spectatorship, and misogynistic narrative convention that Hard Candy and its allusion evoke, this essay explores the ways in which queer feminist currents within and around Foster's body of work and persona subvert normative tropes of gender, reproduction, and emotion through temporal play, a distinctively and chronically tomboyish embodiment, and a cumulatively paranoid outlook.

Foster has constructed her career largely around the type of psychological thrillers from which Hard Candy draws, hence Slade's scripted nod; its chronologically closest precursor is David Fincher's Panic Room (2002), in which she plays mother to a tomboy not unlike Hayley. One of the most excruciating moments of narrative tension in Panic Room--a film that seldom relaxes--involves neither sex nor violence but produces its tension by intimating both. Young Sarah (Kristen Stewart), here supine and incapacitated by illness, plugs her ears in the 
background of a shot while in the foreground a burglar's shrieking drill bites through the lock of a vault. The camera cuts from Sarah to her mother to the burglar in the act of penetration, a disturbingly suggestive sequence until it ends on the burglar's sociopathic accomplice, Raoul (Dwight Yoakam). Raoul howls as the panic room's steel door severs his fingers, a jarring confirmation and obliteration of the eroticism the editing has conjured. If, as Tania Modleski argues, eroticized violence and rape (or its specter, as in this case) are not only common to but in fact constitutive standards of Hollywood thrillers, then a home invasion film pitting a single woman and her eleven-year-old daughter against three ill-intentioned racialized men certainly capitalizes on that tried and troubling pattern. ${ }^{1}$ Yet even as it deploys such clichés as the helpless little girl and the fiercely protective mother, the unorthodox gender dynamics Panic Room enacts ultimately subvert these pernicious discourses and give birth to an embodied female subjectivity that endures, its tomboy duo surviving to prove that their mode of gender nonconformity can persist beyond childhood, contrary to the insistences of mainstream narrative (on which more presently), and that its survival constitutes a kind of queer feminist futurity that refutes both heteronormative ideology and antisocial currents within queer theory.

This futurity hinges` upon the notion of temporal drag Elizabeth Freeman elaborates in Time Binds, the inevitable and visceral "retrogression, delay, and ... pull of the past on the present." ${ }^{2}$ Through the latter, this essay elaborates the dissident configuration of motherhood Panic Room begets via Meg/Foster and Sarah/Stewart's interrelations, one that presents an alternative to oppressive maternal norms and the politico-cultural phenomenon Lee Edelman calls reproductive futurism--an alternative predicated on the particular imprint of Foster's star

\footnotetext{
${ }^{1}$ Tania Modleski, The Women Who Knew Too Much: Hitchcock and Feminist Theory (New York: Methuen, 1988).

${ }^{2}$ Elizabeth Freeman, Time Binds: Queer Temporalities, Queer Histories (Durham, NC: Duke University Press, 2010), 62.
} 
image and its iterations across her corpus. ${ }^{3}$ In refuting the conventional tomboy trope that sees female resistance capitulate in adolescence to heteronormative strictures, Panic Room, I will argue, enables a queer feminist reproductivity through mimetic tomboy embodiment, permitting female gender deviance to endure on-screen in a manner distinct from spinsterhood or phallicism or butchness, all of which are defined in relation to men and masculinity.

This essay takes Panic Room as its foundation, focusing first on the ways in which the film draws on Foster's past roles and their indelibly tomboyish traces to perform such reproductivity through her and her character's interactions with another tomboy actress. Tomboys are nearly always motherless in film, so Panic Room's thematization of the motherdaughter relationship between Foster's and Stewart's characters is rare and fertile ground for inquiry. Indeed, their pairing is precisely what enables the film's articulation of queer futurity and femaleness: its affirmation of tomboyism beyond adolescence and the existence of a defeminized motherhood on narrative and metanarrative levels transcends the film to enact a nonbiological kinship between actors whose affinities exceed their on-screen roles in Foster and Stewart's continued relationship.

Drawing on contemporary critiques and reimaginings of paranoia and thrillers by feminist scholars including Sianne Ngai and Jyotsna Kapur, I then extend this discussion from

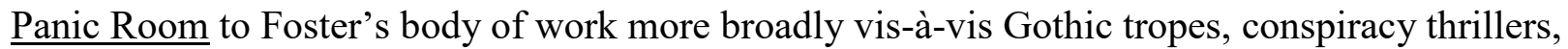
paranoia, and questions of gender therein, arguing that it functions cumulatively as simultaneous evidence and critique of the imbalanced power dynamic inherent in heterosexual and heterosocial relations within the United States. Nearly all of Foster's films treat this imbalance

\footnotetext{
${ }^{3}$ Lee Edelman inveighs against the "for the child" sentiment that dominates late twentieth-century political rhetoric and upholds the "absolute privilege of heteronormativity by rendering unthinkable ... the possibility of a queer resistance to this organizing principle of communal relations" (No Future: Queer Theory and the Death Drive [Durham, NC: Duke University Press, 2004], 2).
} 
through gender-deviant heroines whose potency derives from their accumulation over time, along with the extradiegetic force of Foster's own queerness and feminism--speculated and stated alike. In their citations and refutations of misogynistic convention, Nicolas Gessner's The Little Girl Who Lives Down the Lane (1976) and Robert Schwentke's Flightplan (2005) speak most directly to scholarly debates about domesticity and female paranoia, cinematic or otherwise. In the latter, Foster plays a recently widowed woman whose daughter disappears from a plane midflight. The film constitutes an aeronautic and maternal take on Alfred Hitchcock's psychodrama The Lady Vanishes (1938), where women are made to question their own powers of observation in the face of conventional authority. Flightplan's conspiracy formula, thematized disruption of female-female relations, and reinscription of ostensibly failed motherhood cast, in the context of Foster's oeuvre, a critical gaze upon gendered discourses around paranoia, intellect, and generic convention. Little Girl finds Foster motherless as Rynn Jacobs, a reclusive orphan whose seemingly exaggerated fears about interpellation into state systems also prove

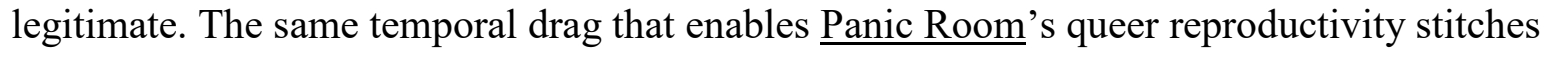
Foster's films together across time in a way that consolidates their aggregate position of paranoia and the pernicious tropes and ideologies from which it stems into a unified commentary accessible to the sustained gazes of those chronic viewers of her work. This mode of paranoia qua theory accordions outward across history in Foster's oeuvre, locating elements of conspiracy not simply in discrete diegeses but in overarching, transhistorical narratives directly linked to questions of celebrity, tomboyism, and spectatorship, as well as domesticity and motherhood. By harnessing the queer feminist residue that inheres in her star image, moreover, Foster and her oeuvre expose and critique the extent to which filmic convention--and, by extension, cultural convention--is predicated on heterosexist norms. 


\section{Untaming the Tomboy}

Foster's Hollywood career began with a Coppertone sunscreen commercial and took off through a succession of spirited, ostentatiously ungirly heroines. Despite the tomboy's staple status in cinematic typology even beyond Foster, no satisfactory definition of tomboyism has emerged within what is a surprisingly small amount of critical work on the topic, nor even much consensus on its characteristics. A vast range of traits and behaviors prompt attributions of tomboyism, from an affinity for horseback riding (Elizabeth Taylor in National Velvet, 1944) to having short hair and spunk (Tatum O'Neal in Paper Moon, 1973) to the act of entrapping and torturing pedophiles, as Hayley does in Hard Candy. Michelle Abate and Karin Quimby, however, have written persuasively on the figure of the tomboy in literature and the resistant reading practices that queer and feminist audiences may employ to counter the subjugation of queer and feminist subjectivity that such narratives perform. Hollywood's tomboy films are generally characterized by ostentatiously heteronormative endings that cram the theretofore resistant heroine into a putatively happy pairing with the male lead and strip her of many of the attributes that distinguish her throughout. Abate argues that the definitive feature of such films is precisely this phenomenon of "tomboy taming," a narrative process that seeks "to eradicate-ideally by choice, but if necessary by force--a gender-bending girl's iconoclastic ways and have her adopt more feminine behaviors . . . with the onset of puberty." ${ }^{4}$ But the added textures of celebrity presence and the tendency of certain actors to appear chronically as tomboys (e.g., Foster, Stewart, Page, and O’Neal, as well as Mary Stuart Masterson, Kristy McNichol, Lori Petty, and Jena Malone) warrants further attention. Filmic tomboy narrative--examples of which

\footnotetext{
${ }^{4}$ Michelle Abate, Tomboys: A Literary and Cultural History (Philadelphia: Temple University Press, 2008), 31 .
} 
include Billie (1965), Bad News Bears (1976), Foster's own Freaky Friday (1976), Some Kind of Wonderful (1987), and Her Best Move (2007)--almost invariably constructs tomboyism as finite and acceptable only up to the point of adolescence, at which time it comes to be perceived as a symptom of pathological gender deviance and, implicitly, lesbianism. For the purposes of this essay, then, the term "tomboyism" denotes qualities out of sync with the normative trajectory of feminine heterosexuality as conventional film narrative figures its progression from demure girlhood to subservient wifedom or its premarital equivalent. ${ }^{5}$

Much work has been done by such critics as Linda Badley, Jeffrey Brown, Barbara Creed, Carol Clover, Sherri Inness, Jack Halberstam, Tania Modleski, Yvonne Tasker, and others on androgyny and phallicism in horror and action heroines, but most of it focuses on adult characters rather than children and tends to remain moored in dichotomous constructions of gender. Despite possessing what Tasker has termed "musculinity," female action heroines remain highly sexualized, and they bear some relation to those spirited if less lethal heroines of comedic and dramatic tomboy narratives in the ambivalence that surrounds their arguably transgressive embodiment. Brown, further, contends that action heroines' combination of exaggerated masculine and feminine traits speaks to a conflicted negotiation of traditionally sexualized representations of women with changing gender expectations. ${ }^{6}$ However, this essay seeks to reframe the questions of gender at stake in filmic treatments of deviant femaleness in terms of temporality, rather than masculinity and femininity, and the affective dimensions and chronological contingencies that distinguish tomboy narrative call for this refocalization.

\footnotetext{
${ }^{5}$ Yvonne Tasker, Spectacular Bodies: Gender, Genre, and the Action Cinema (New York: Routledge, 1993).

${ }^{6}$ Jeffrey Brown, Dangerous Curves: Action Heroines, Gender, Fetishism, and Popular Culture (Jackson: University Press of Mississippi, 2011).
} 
Foster, a chronic tomboy actress who has made consistent and notorious appearances in films that engage directly and indirectly with questions of feminism and sexual violence, makes for an especially compelling case study along these temporal lines. ${ }^{7}$ Many of her childhood roles follow the expirational model of tomboyism Abate lays out, including Napoleon and Samantha (1972), Freaky Friday, and Candleshoe (1977). In Friday, Foster's Annabel and her mother magically switch bodies, and the recalcitrant daughter's encounter with adult femininity renders her meeker, milder, and wiser enough to win over the boy who earlier found her repulsive; in the final scene, she primps in front of a mirror before heading out with him on a date. Richard Dyer contends that "a star's image is made out of media texts" that exceed any single performance, incorporating such peripheral factors as marketing tactics, prior roles, and "audience foreknowledge" about the actor. ${ }^{8}$ Per Dyer's formulation, Foster's screen presence inevitably calls up the resistance to gender norms and the constant thematization of rhetorical, physical, and sexual violence against women among her various roles.

Indeed, this relentless focus of her work on questions of gendered and sexualized violence distinguishes Foster's tomboyish star image from that of her contemporaries. Foster is a rare example among her generational cohort of a tomboyish child actress whose celebrity has survived the transition to adulthood. O'Neal's career, for instance, waned in her teen years, and McNichols's tapered off in a series of unheralded heteroromantic comedies. Moreover, Hayley's

\footnotetext{
${ }^{7}$ Foster has played prostitutes in Taxi Driver and Shadows and Fog (1991); a gangster moll in Bugsy Malone (1976); an exotic dancer in Carny (1980); a victim of sexual abuse and/or rape in Little Girl, The Hotel New Hampshire (1984), My Letter to George (1985), Five Corners (1987), and The Accused (1988); in Nell (1994), her character's birth is the result of rape. The French production Moi, fleur bleue (1977) features Foster as an underage schoolgirl who initiates a relationship with an older man. In Catchfire (1990), Foster's character witnesses a mafia hit and is subsequently stalked by two mobsters, one of whom falls in love with her and blackmails her into a sexual relationship that she soon embraces. The other mobster is played by John Turturro, whose character stalks and rapes Foster's Linda in Five Corners.

${ }^{8}$ Richard Dyer, Stars (London: BFI, 1998), 10.
} 
line in Hard Candy at once attests to and posits anew Foster's feminist stance and chronic engagement with sexualized violence and eroticized childhood through the latter's queerly gendered heroines. As an in-joke, too, it presupposes an affiliation between that film's audience and Jodie Foster's fans; this hypothetical cross section's sustained investment in actresses who consistently play resistant female characters across time indicates that the potency of $\underline{\text { Panic }}$

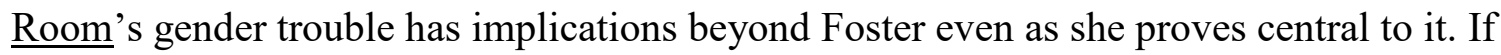
heteronormative ideology is paranoid about tomboys and their relation to female insubordination, as narrative convention and the trope of tomboy taming indicate, then Foster's body of work, with all its resistant figures incarnated as tomboys and otherwise, evinces a metaparanoia about that ideology's phobic position--a position that Foster counters by repeatedly and differently presenting dissident bodies within that corpus.

\section{Panic Womb?}

Female paranoia, according to Sigmund Freud, is based in the pervasive fear of violent and violative masculine spectatorship. This fear or, more aptly, this understanding has stood as the foundation of feminist film theory for decades, and through the aggregate force of her roles, Foster's corpus critiques the inimical patterns their accumulation makes manifest. In and alongside Panic Room, the paranoia Foster's films perform provides a counterpoint to patriarchal paranoia about deviant femaleness (here tomboyism), insistently emphasizing the injurious effects of omnipresent misogyny and its conscription of such resistance in narrative into the service of heteronormative reproductivity. This argumentation reworks critical discourses in gender theory and feminist film scholarship that often rely on dichotomous conceptions of gender and reject the possibility of subversive feminist politics within mainstream commercial film and the commodified figure of the celebrity. 
Feminist critics have long debated the merits and limitations of the kinds of gynocentric domestic thrillers in which Foster so frequently appears, especially the cycle of 1940s psychodramas whose Gothic plots thematize knowledge, visual agency, and the frail acuity of female intellect; while Panic Room is very much a product of its historical moment (a trend of wealthy families installing in-home panic rooms inspired David Koepp to begin the script in 2000), it also reflects long-standing cinematic conventions and cultural discourses around sex, gender, and sexuality. Dating back to what Mary Ann Doane terms the paranoid woman's films that emerged in and around World War II (Gaslight, Possessed, The Locket, Johnny Belinda), Hollywood film posits a significant semantic difference in a male's home being broken into versus a female's. ${ }^{9}$ A man's relation to his house, traditionally, is economic: the measure of professional success. According to traditions of womanhood, however, the domestic sphere the house encompasses is her primary and proper domain. Such an experience for heteronormative males might register as emasculating in a pecuniary sense, a violation of material wealth and property. For females, the threat is immediately sexual, as penetration of the home implicitly presages penetration of the body. From Rosemary's Baby (1967) to Panic Room, the invasion of a female's space by males necessarily becomes a political allegory evoking reproductive rights discourses and the American right wing's repeated incursions into women's autonomy via the body. Reproductive discourses remain a primary means by which a misogynistic society discredits and disenfranchises women, so motherhood itself remains an essential site for feminist interrogations, and filmic representations of it are a rich venue through which to pursue them.

\footnotetext{
${ }^{9}$ Mary Ann Doane, The Desire to Desire: The Woman's Film of the 1940s (Bloomington: Indiana University Press, 1987).
} 
As one such representation, Panic Room--though at first glance an unexceptional thriller about a woman and her daughter forced to retreat to their home's eponymous safety chamber when burglars break in--works, in light of Foster's oeuvre and its feminist bent, on a level deeper than mere titillation at the women-in-danger plot. John Kitterman claims that "it is clearly [the] contest between the sexes that attracts the American moviegoer" to Panic Room, but such moviegoers will be disappointed to find that its lone mutilated bodies belong to white men and that the ostensible battle of the sexes is, more accurately, a collision of gendered performances within a single body. ${ }^{10}$ Panic Room is in many ways a feminist film, one that defies generic expectations, that sees its "final girl" figure become less naked, less vulnerable, and less sexualized as the film progresses. ${ }^{11}$ By accessing a buried tomboyish past, Meg cultivates emancipatory faculties for self-awareness and aggression and finally proves herself capable of deploying gendered performances to her advantage.

Having gained tremendous popularity during the Cold War, home invasion films are characterized by intruders who enter a residence with some nefarious aim. Among the subgenre's primary conventions is the "breakdown of alliances," a consequence of which is the dissolution of intrafamilial trust and the further isolation of each faction within the home. Panic

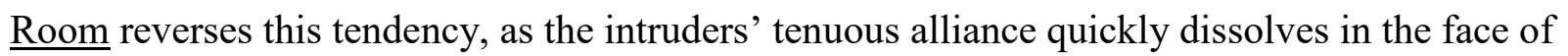
the mother's and daughter's resistance, highlighting the potency of this seldom-depicted intersectional cooperation. The film is largely about the complication of many of the very tropes it employs to capture the interest of mass audiences: criminal Others, "helpless" women

\footnotetext{
${ }^{10}$ John Kitterman, "Home(land) Invasion: Poe, Panic Rooms, and 9/11," Journal of American Culture 26 (2003): 239.

${ }^{11}$ Clover's term for the androgynized female character in horror films who survives to confront the killer. See Men, Women and Chainsaws: Gender in the Modern Horror Film (Princeton, NJ: Princeton University Press, 1997).
} 
in danger, a vulnerable child isolated with racialized villains. It challenges notions of gender and genre to propose a refigured version of motherhood and, through a mother's interactions with her tomboy daughter (this aspect of Panic Room is in itself exceptional; tomboy characters in film and literature are nearly always motherless), novel possibilities for tomboyism beyond childhood. Premised on Foster's star image to the extent that a viewer unfamiliar with her work might find her character implausible if not entirely incoherent, it demands to be understood in relation to Foster's history and the construction of film genre and celebrity more broadly, as the categories it questions and the possibilities it posits must also be. The mode of gendered reproductivity that emerges through the film's form and narrative alongside its relation to cultural attitudes and the ongoing histories of its stars comprises a starting point from which to think about female agency as a matter not of masculinization but of reclaiming autonomies of youth and wielding them in resistant relation to heteropatriarchal constraints.

\section{Failed Femininity and Mediocre Motherhood}

While on one level Panic Room critiques a society that prioritizes and commodifies the safety of the white upper class, it also thematizes a topic rare within its genre and tomboy films alike: mother-daughter relationships. ${ }^{12}$ Briefly, the film is a psychological thriller about Meg and Sarah Altman, whose new home is broken into by three working-class men who know that the previous owner has stashed bank bonds worth several million dollars in the floor of the titular space. Foster plays the perpetually tense Meg and Kristen Stewart her snarky, tomboyish daughter. Meg must protect Sarah--who is prone to diabetic shock--and find a way to expel the burglars. When she leaves the panic room to find Sarah's medicine, the intruders enter and lock themselves in

\footnotetext{
${ }^{12}$ James Swallow, Dark Eye: The Films of David Fincher (London: Reynolds \& Hearn, 2003), 150.
} 
with the girl. In the climactic showdown, Burnham (Forest Whitaker), the most reluctant burglar, saves Meg by killing the most vicious, Raoul, who has earlier murdered Junior (Jared Leto), the heist's original mastermind. Recently divorced from pharmaceuticals tycoon Stephen Altman (Patrick Bauchau), Meg possesses a contradictory assortment of attributes. One moment struggling with technology, the next hotwiring telephone lines, she is equal parts ungainly parent and la femme Nikita; this deceptively complex character proves to be a calculated agglomeration of Foster's roles over the years.

From the beginning, the film casts Meg as an incompetent mother. She bickers ineffectually with her daughter, orders pizza instead of providing a home-cooked meal, and is repeatedly preempted in discipline by her hyperfeminine realtor, who does not hesitate to rebuke Sarah for riding her scooter inside the brownstone. Meg is meek and flustered, scolding her daughter at the wrong times and later lapsing into oversentimentality. "I love you so much it's disgusting," she tells Sarah, tucking her into bed, and she is right: viewers are accustomed to Foster's tough, consummately self-possessed characters, children and adult alike, from spunky Audrey in Alice Doesn't Live Here Anymore (1974) to Clarice Starling in The Silence of the

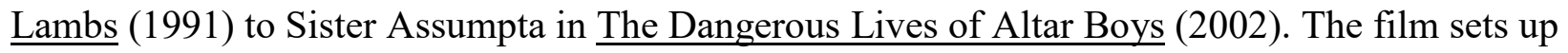
Foster-as-Meg as someone alien to audiences, an irreconcilable mishmash of ineptitude, passivity, and ex-trophy wife status; this disruption of expectation heightens the pervasive sense of unease.

Although Foster's personality as Meg may seem like foreign territory to viewers, motherhood has been under cinematic and feminist scrutiny since the medium came into existence. Here, we watch a mother recently divorced from (but still fiscally bound to) a prototypical American patriarch become a loud, present, and centralized node of agency only 
after attempting and failing to achieve maternity's ideals. Eminent feminist scholars such as Doane, Ann Kaplan, Laura Mulvey, Lucy Fischer, and Barbara Creed have devoted attention to the figure of the mother in popular film, but their work prioritizes the femme fatale, the sacrificial mother of maternal melodrama, or the phallic mother of Hitchcockian thrillers. As Linda Ruth Williams writes, Panic Room “unpacks a number of genre staples," most notably the "woman in peril"-cum-Final Girl trope Clover and Modleski have so articulately analyzed. ${ }^{13}$ Its maternal protagonist thus fits into neither the sacrificial nor the phallic category. Rather, Meg becomes a hybrid entity, still prepared to make the ultimate sacrifice for her child but newly equipped with sufficient wherewithal to foreclose its need.

To access this potency, Meg must break with the linear chronology of traditional character development and reach backwards and sideways toward her past and Foster's, as well as the model her daughter embodies. Freeman advances the concept of erotohistoriography as a recuperative method of encountering the past through bodily performances and nonnormative behaviors. Erotohistoriography "does not write the lost object into the present so much as encounter it already in the present. ... And it uses the body as a tool to effect, figure, or perform that encounter. Erotohistoriography admits that contact with historical materials can be precipitated by particular bodily dispositions and . . responses . . . that are themselves a form of understanding." 14 Although Freeman conceives it as a reparative critical praxis, erotohistoriography functions here through an actor's performance and a spectatorial act by viewers who inevitably see a performance in relation to past performances. Meg/Foster encounters the lost object of tomboyism (and its attendant autonomy) in the person of her daughter and the repetition — with a difference — of an assemblage of her previous roles, her body

\footnotetext{
${ }^{13}$ Linda Ruth Williams, "Mother Courage," Sight and Sound 12 (2002).

${ }^{14}$ Freeman, Time Binds, 95-96.
} 
of work through a period of history. The moment that marks Meg's encounter with her abandoned/forsaken tomboy youth is one of eros indeed, ending in a self-shattering scream as she cradles her own tomboyish child while watching Stephen being savagely beaten—on which more later.

Time in Panic Room is both condensed and prolonged: circumstances change completely in mere instants, yet the night drags on for what seems like hours. The camera creeps slowly through the house, and the film's bispatial structure occasions a perpetual alternation between Meg and Sarah and the burglars that lends a layer of thickened duration to every scene. In temporal terms, Meg's character is marked by behindness, slowness, and delay. She has discovered her husband's infidelity too late, she struggles with technology, she is far from "with it" enough to satisfy her sarcastic daughter. This belatedness eventuates from a sense of rush congruent with Gothic convention, wherein women's hasty marriages introduce their barely acquainted husbands as mysterious, threatening figures. ${ }^{15}$ Meg has left school early and bought the brownstone too quickly, so to survive - to move forward — she must move back to a time before all this, paradoxically, to previous roles and attitudes, and, most importantly, to the tomboyism that her daughter still possesses. Freeman's notion of temporal drag manifests itself in Sarah's youthful autonomy pulling Meg back toward her own predomestic(ated) days and in Foster's acted and lived pasts, which emerge here as a cumulative persona--and a recuperative countermand to the rush that has precipitated Meg's adverse situation.

The beginning of the film advertises Meg's failed attempts at archetypal femininity as the root of that situation: she has lost her adulterous husband to a younger woman and quit school to be a mother, which in turn has left her jobless, out of touch, and dependent on her ex-husband's

\footnotetext{
${ }^{15}$ Diane Waldman, “'At Last I Can Tell It to Someone!': Feminine Point of View and Subjectivity in the Gothic Romance Film of the 1940s," Cinema Journal 23, no. 2 (1984): 29.
} 
money. This uncomfortable position elucidates the insufficiency of dichotomous conceptions of gender; an unfeminine woman, of course, is not equal to a masculine woman, and to designate the changes Meg undergoes throughout the film as masculinization would flatten the very distinction Foster's roles so often make in resistance to the over-valorization of masculinity. But beyond the fact that "unfeminine" and "masculine" are not coterminous, Meg's dislocation sets the stage for her to regain through the film what has been a gradual loss of agency embodied in the transfiguration of her gender. The film conveys her sexual abjection visually through camerawork and costuming, particularly by contrast to Sarah's demeanor and dress. After bathing--an unmotivated scene rife with lingering, melancholy-fraught close-ups--Meg dons a low-cut pajama top, which emphasizes her vulnerability through exposed flesh and attaches to her a perpetual connection to bed, with all the connotations that carries.

In light of her ostentatiously ill-suited femininity, where does Meg fall on the gender spectrum? Is "spectrum" a useful figure through which to think about gender as an embodied phenomenon? As Halberstam has demonstrated, American society finds masculinity easy to recognize, difficult to define, and nearly impossible to conceive of in relation to females. Eve Sedgwick advocates conceptualizing masculinity and femininity as orthogonally related rather than diametrically opposed--a useful schematic, although it does little to flesh out the term itself. ${ }^{16}$ Depictions of masculinity tend to entail physical and emotional strength, autonomy, agential visuality, and as Halberstam notes, the "greater freedoms and mobilities enjoyed by boys," all of which figure prominently in Meg's transformation; the latter half of the film also puts the gaze--a cornerstone of male cinematic subjectivity--under Meg's control. ${ }^{17}$ However, in

\footnotetext{
${ }^{16}$ Eve Kosofsky Sedgwick, "Gosh, Boy George, You Must Be Awfully Secure in Your Masculinity!," in Constructing Masculinity (New York: Routledge, 1995), 15-16.

${ }^{17}$ Judith Halberstam, Female Masculinity (Durham, NC: Duke University Press, 2006), 6.
} 
the spirit of advancing a more Butlerian model in which no sex is intrinsically masculine or feminine, I would propose, contra Halberstam's incorporation of tomboys into a binaristic schema, that appropriating those freedoms and mobilities (which in tomboy film include the freedom not to be paired off with the opposite-sex lead) granted to males does not amount to masculinity. Instead, and beyond the hegemonically endorsed masculinization of the fiercemother figure in service of the nuclear family, the gender trouble the film locates in Foster's body disrupts the categories of masculinity and femininity through the retroactive nurturance_of tomboyism, proffering as an alternative a resistant combination of the two made greater than the sum of its parts by the temporal play that accompanies it. ${ }^{18}$

\section{Like Daughter, Like Mother}

Moreover, the presence of not one but two markedly unfeminine females in a Hollywood thriller is all but unheard of, and the combination proves worthy of the anxieties that conventionally force deviant girls into heteronormative compliance as this tomboy instead reproduces her resistance in another. Like Annabel pre-taming, Sarah embodies a freedom and mobility that defy traditional feminine constrictions from the start. She skims the streets confidently on her scooter and eagerly explores her new home; the camera accords her an off-screen autonomy even as it pins Meg down in dark corners and with tight close-ups. Sarah ranges freely and speaks her mind openly, a vivacious foil to her mother's quiescence and brittle passivity. Although her illness later immobilizes her, Sarah's early behaviors model what Meg must do to save them

\footnotetext{
${ }^{18}$ The fiercely protective mother is herself what Williams refers to as a "genre staple," one that grants conditional autonomy contingent upon this provisional agency's service of the nuclear family / patriarchal imperatives, from Barbara Stanwyck's character in Stella Dallas (1937) to Foster's own in Neil Jordan's The Brave One (2007), who embarks on a vigilante killing spree to avenge her fiancé's murder. See Williams, "Mother Courage."
} 
both, that is, move with autonomy through the house, claim her physical agency, and stop swallowing the "fuck her" attitude Sarah voices toward Stephen's mistress and for which Meg reproaches her in their dinner scene. Through the unconventionally pedagogical daughter-mother dynamic that develops over the course of the film, Panic Room enacts an erotohistoriographic reversal of the tomboy narrative, bringing Meg's lost autonomy of gender into the present and staking a claim for a mode of resistant womanhood not reducible to the category of butchness.

No female intuition or motherly clairvoyance alerts Meg to the presence of intruders. On the contrary, two elements with distinctively unfeminine connotations tip her off: first, Meg's glance toward the panic room that becomes a gaze into the security monitors, and second, the loudly bouncing basketball—another marker of Sarah's tomboyism—-that Junior accidentally kicks down the stairs. As if to emphasize the significance of her gaze, Meg stares directly into the camera before it cuts to one of the rare point-of-view shots in the film: a security monitor captures the burglars ascending and forces the viewer into uncomfortable identification with them. In the symbolically rich basketball and moment of surveillance, this scene incorporates both elements that Meg must wield to her advantage to survive the night and save her child. Further, the staging of the film's gendered inversion of vision on a staircase (as Doane observes, "It is on the stairway that [the Gothic female protagonist] is displayed as spectacle for the male gaze") positions Panic Room conspicuously and self-consciously out of step with its generic predecessors. ${ }^{19}$

Once safely ensconced within the chamber's reinforced walls, Meg reverts to damsel-indistress mode, though not for long. She sits, cowering and cradling Sarah, and in the meantime Burnham disables the alarm and phone systems and tells Sarah, simply, "We wait." While Meg

\footnotetext{
${ }^{19}$ Doane, "The Woman's Film," 288.
} 
slumps despairingly, Sarah rifles through the panic room's supplies and finds a flashlight with which she almost manages to alert their neighbor before dropping it down the drainpipe. Eventually, and only with Sarah's encouragement, Meg begins to take advantage of her home's technology, using the PA system to threaten the burglars--but when they call her bluff she surrenders, instructing them to "take what [they] want and get out!" They inform her that what they want is in the panic room--which must register with the Altmans as a threat of bodily harm, since they remain unaware of the hidden bank bonds. Yet oddly at this moment of extreme narrative tension, as if to affirm that the film is more concerned with reconceiving motherdaughter relations than provoking grisly sensation, Fincher inserts one of the sole comical scenes, as Sarah teaches her mother to curse effectively:

MEG: Get out of my house!

SARAH: Say “fuck.”

MEG: . . f fuck!

SARAH [exasperated]: Mom. "Get the fuck out of my house."

MEG: Oh. Get the fuck out of my house!

By rupturing the narrative's relentlessly grim tone, this humorous exchange announces its own importance, that is, its designation of the sole beacon of hope and resistance in Meg's youthful, tomboyish reflection of herself. Although it locates the "solution" in the child, Panic Room does so without projecting the reproductive futurism to which Edelman so persuasively objects, nor does it forsake the postreproductive adult. Indeed, it forgoes the generic call for maternal sacrifice and reinvigorates Meg as an unfeminine mother and an agential single woman.

Hollywood typically pathologizes such women as neurotic, frigid, queer, or in other ways lacking, but both Freeman and Panic Room refute the negative connotations of resistant 
womanhood and feminism, its corollary. Freeman conceptualizes temporal drag as part of a reparative project on lesbian feminism, whose advocates, she notes, "in many classroom, popular, and activist discussions ... and sometimes in academic scholarship too are cast as the big drag," complainers, disrupters and delayers of the naturalized course of things. ${ }^{20}$ In Panic $\underline{\text { Room, }}$ of course, Foster--an avowed feminist and semi-avowed lesbian--plays one other figure consistently cast in popular film as well as art, literature, and academia as the "big drag," that is, a mother: the nag, the termagant, the spoiler of fun and enforcer of duty. Feminized fathers make common comedic fare, featuring endearingly in films such as Mr. Mom (1983), Sleepless in Seattle (1993), Mrs. Doubtfire (1993), and Big Momma's House (2000), but defeminized mothers remain the province of melodrama, thrillers, and horror. The very thought of such a woman seems to threaten the patriarchal structures--here exemplified through the financial and professional impotency to which marriage and its ideals have circumscribed her--from which Meg must escape, and only by destabilizing them through her own specifically gendered performance can she. ${ }^{21}$

\section{Star Travels: From Silence to "Fuck You!"}

Sarah continues to parent from youth amid the chronological contortions that (re)birth Meg's tomboyism. The former's wristwatch, fittingly, cues that new life to commence: the device tracks not time but insulin levels, contributes an additional layer of suspense by constantly signaling her vulnerability, and expedites Meg's deliverance from feminine norms, its shrill alert impelling her to leave the panic room to retrieve her daughter's medication. Finally, and only after watching

\footnotetext{
${ }^{20}$ Freeman, Time Binds, 62.

${ }^{21}$ Ann Kaplan, Motherhood and Representation: The Mother in Popular Culture and Melodrama (New York: Routledge, 1992), 111.
} 
Stephen's vicious beating at Raoul's hands, Meg emerges from the womblike safety of the chamber. She lets loose an earsplitting primal scream that marks a moment not so much of throwing off the strictures of "civilized" society as of a shattering recognition of their effects.

In this peripeteic instant, Meg's dilute personality commences the process of being dragged, thickened, and made tangible by the substance and citation of Foster's prior roles as well as Sarah's tomboyish influence. In addition to endless public speculation about her sexuality, Foster's past and its perdurance provoke in viewers what Karen Hollinger describes as “a tendency ... to see Foster's performances as lacking 'romantic chemistry' with her male love interests." 22 Foster's perceived failure to create convincing erotic connections with male leads lays the groundwork for the pronounced gracelessness of Meg's attempts at heterofemininity. Unfair though this position of speculative viewership may be, its inevitability is well documented in celebrity studies. Beyond Dyer's notion of a star image that accrues from individual media texts, Barry King observes that stars establish over time a "wardrobe of identities" viewers consider credible rather than any one unified persona, and Leo Braudy argues that "film acting deposits a residual self that snowballs from film to film" over which directors and scriptwriters have limited control. ${ }^{23}$ For better or worse, moreover, a star's image is often deployed for marketing purposes regardless of its (ir)relevance to the film in question. To this point, Columbia Pictures initially insisted, despite Fincher's objections, on marketing Panic Room as "the new

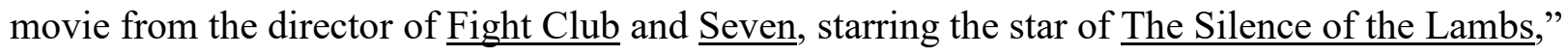
resulting in a "cross-section of audience that this movie was not made for"--an audience that,

\footnotetext{
${ }^{22}$ Karen Hollinger, "Jodie Foster: Feminist Hero?," in Pretty People: Movie Stars of the 1990s, ed. Anna Everett (New Brunswick, NJ: Rutgers University Press, 2002), 54.

${ }^{23}$ Barry King, "Articulating Stardom," in Stardom: Industry of Desire, ed. Christine Gledhill (New York: Routledge, 1991), 168; and Leo Braudy, The World in a Frame: What We See in Films (Garden City, NY: Anchor Press, 1976), 419.
} 
whatever its undesirability to Fincher, would carry cognitive associations with Silence and related expectations into theaters. ${ }^{24}$

Critics and audiences alike make frequent reference to Foster's previous roles in assessing Panic Room. Williams notes several moments that recall Foster's $\underline{\text { Silence }}$ role as FBI agent Starling, describing the sequence in which Meg "nips around the darkened house ... [as] reminiscent of the [Silence] final chase" and asserting that Meg "reprises something of the "Final Girl' aspect of Clarice Starling." ${ }^{25}$ Williams comments on Foster's numerous single-mother roles, from Little Man Tate to Anna and the King (1999), though many roles that bear attention for their underlying relation to this film are older--films like Alice Doesn't, Taxi Driver (1976), Bugsy Malone (1976), Candleshoe (1977), and Foxes (1980), in which she plays children characterized by self-sufficiency and preternatural competence. In these films, too, motherdaughter relations are at best nonexistent and at worst homicidal; such singular continuities among Foster's roles generate feminist currents far stronger than the individual films on their own.

The inevitable influence of Foster's star image on audience reception constitutes another manifestation of temporal drag, as Foster's past pulls on Stewart's present: for all intents and purposes in Panic Room, Kristen Stewart is in drag as a young Jodie Foster. Different as Meg and Sarah are in temperament, the film constructs a strong physical resemblance between them. The camera consistently frames the two together, mirroring each other's movements and exhibiting similar postures and facial expressions. Meg's hairstyle, too, resembles Sarah's but is longer, as if grown out to achieve a more feminine look. Swallow notes that "even before Foster

\footnotetext{
${ }^{24}$ Swallow, Dark Eye, 171.

${ }^{25}$ Williams, "Mother Courage."
} 
had been cast, Sarah's part was filled on the basis of similarity to the actress. 'We saw Kristen Stewart,' said Fincher. 'We thought she was amazing, like a young Jodie Foster.”'26 Indeed, Stewart's performance as Sarah, a filmic tomboy par excellence with androgynous haircut, athletic accountrements, and energetic independence, recalls any number of Foster's younger roles, from Rynn in Little Girl to Friday's Annabel: self-assured, sarcastic, and endearingly precocious. It is rare in Hollywood cinema for a girl to exhibit deviant gender characteristics unless that deviance (and, typically, its eradication) constitutes a significant part of the plotline; whatever the notoriously meticulous Fincher's reasoning, the choice evokes Foster's own past tomboy roles, illuminates the mother-daughter dynamic as it evolves, and highlights the play of gender throughout the film (surely a Panic Room as originally cast with Nicole Kidman and Hayden Panettiere would have a wholly different tone). Tomboyism aside, Sarah is a child befitting of the thriller genre--unaccountably savvy, ethereally frail, gently contemptuous of her mother's technological ineptitude and displays of affection. Like so many resourceful self-parenting children in American narrative, she knows the tricks to manipulating elevators and where to find vents when the burglars fumigate the panic room, but her illness keeps her within the realm of affective relatability. Sarah suffers from type 1 diabetes, a chronic disease in which an autoimmune reaction destroys insulin-producing cells that integrate glucose into one's system. Instead, the glucose remains in the blood, causing fatigue, nausea, and, if untreated, diabetic shock followed by death. Although it may be a stretch to call Sarah's condition a psychosomatic rejection of sugar and spice and all things nice of which girls are proverbially made, it nonetheless serves an important and specifically gendered function beyond

\footnotetext{
${ }^{26}$ Swallow, Dark Eye, 161.
} 
merely injecting an additional element of suspense into the plot: it forces Meg out of the panic room and into her own body.

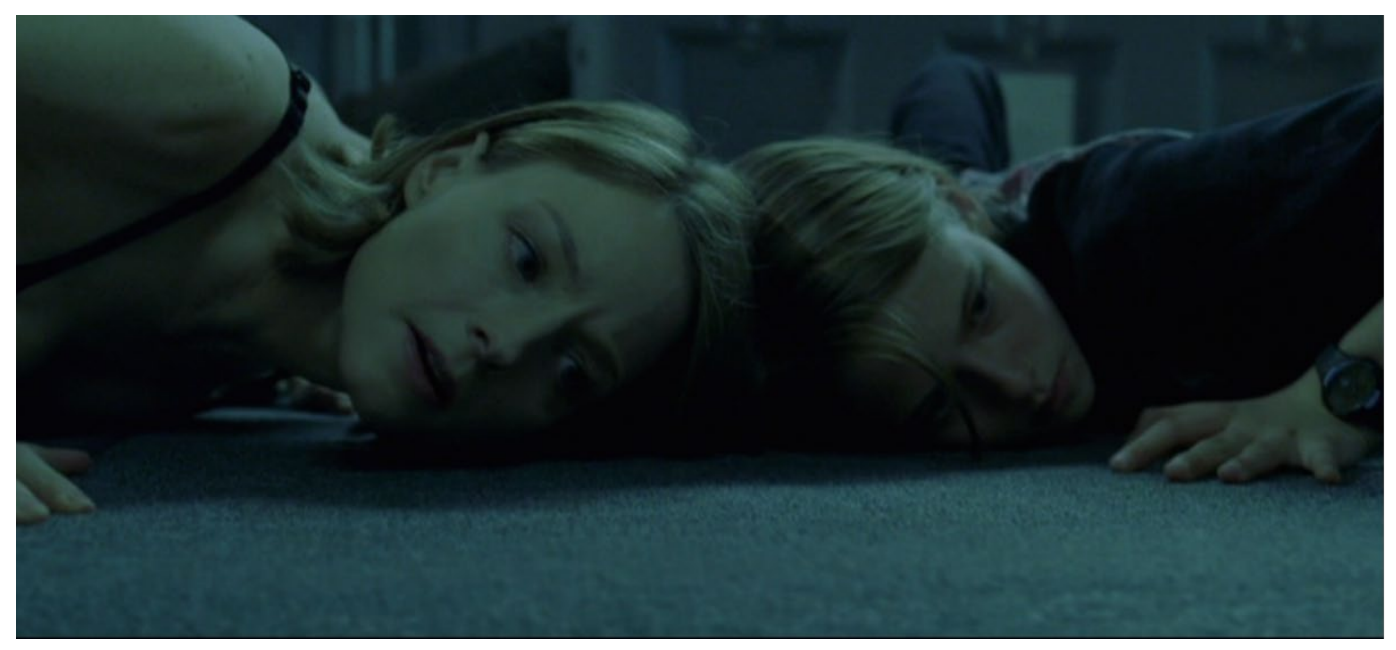

Figure 1. Meg (Jodie Foster) and Sarah Altman (Kristen Stewart) gazing at the security monitors (C Columbia Pictures 2002).

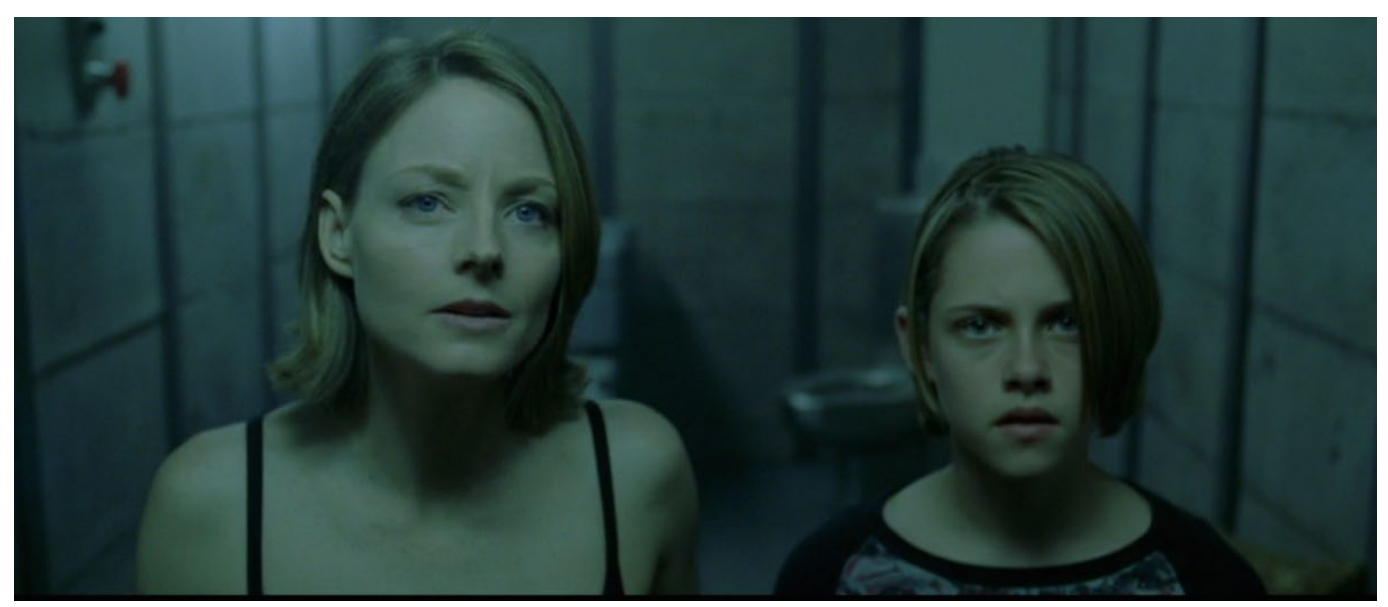

Figure 2. Meg and Sarah Altman listening for the burglars (ㄷ Columbia Pictures 2002).

The police initially arrive soon after Sarah's diabetic episode. Meg must dissuade them from entering in order to protect her daughter, currently trapped in the panic room with Raoul and Burnham, and all three watch intently on the monitors. Meg pulls a bulky sweater over her camisole, obscuring her vulnerable form and effectively defeminizing herself. This wardrobe change served pragmatically to conceal Foster's pregnancy; diegetically, it desexualizes Meg in the viewer's eyes. That this shift occurs immediately before she puts on a self-referential, 
ostentatiously feminine performance accentuates the process of her transformation and her quickly increasing, Starling-worthy competence, and she proves significantly better at feigning femininity than at earnestly attempting to attain its ideals in parenting. Starling strategically

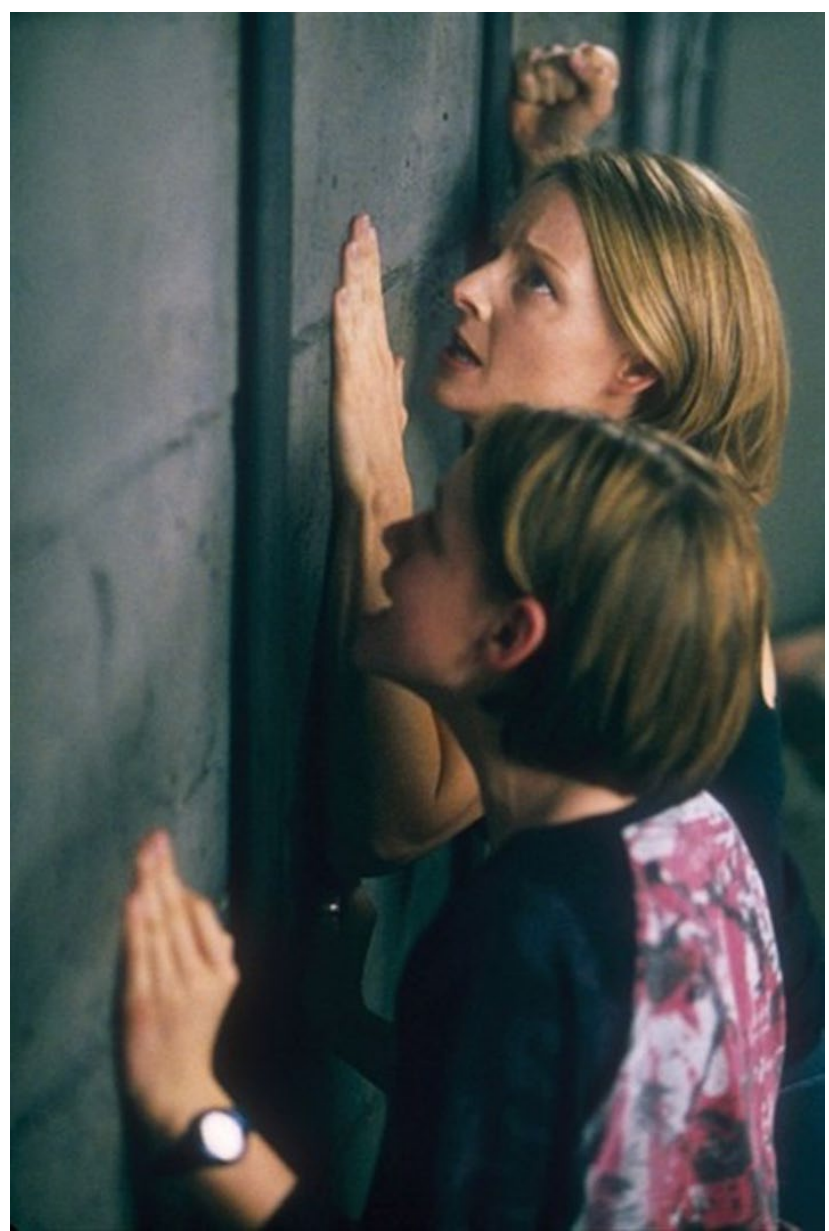

Figure 3. Meg and Sarah Altman calling for help (ㄷ) Columbia Pictures 2002). affects a feminine manner to distract interfering male authority figures at key moments in Silence, most notably in an autopsy scene featuring a female murder victim. She exudes an uncharacteristically matronly air for the local sheriff and his men, framing her request to be left alone with the body as "women's business" so that she might proceed uninhibited by their intrusive stares, directed at her as often as at the corpse in question. Here, Meg deflects the police by professing that her telephone call to Stephen was a desperate, innuendo-ridden entreaty to entice him over. This scene feels remarkably

embarrassing to the viewer, as it self-consciously sexualizes Meg in a manner anathematic to Foster and her oeuvre, recalling by antithesis the customary independence, self-possession, and obscured (or violated) sexuality of her roles.

Capitalizing on this vampish display to stage a dramatic contrast in the scenes that follow, the film highlights Meg's renascent tomboyism through her subsequent interactions with Stephen and the burglars. When the latter address her from the panic room, she looks directly 
into the camera (a point-of-view shot from the security monitor, Meg's and the intruders' earlier positions now reversed) and delivers a muted but emphatically_visible "fuck you!" to return and repulse the male gaze. In recuperating her tomboyism, Meg ascends to a physical potency that extends her prior rejection of that gaze. She smashes the cameras one by one, blinding the burglars to her movements and creating the cover she needs to execute her plan. Newly authoritative, she issues stern directives to the battered Stephen: "Raise your arm. Come on, raise your arm.... Try again. Try again!" Gone are her hesitations, questions, and deference to everyone around her. She rigs him up with a chair and lamp, bracing his broken arm to grasp the gun she wedges into his hand; she enacts her newfound agency upon him such that he, formerly an obstacle to her autonomy and origin of her morosity, becomes an accessory to her survival.

\section{Reputation with a Difference}

The climactic scene centralizes the film's masculine entities only to destabilize their authority in a manner that has become a hallmark of Foster's work. Burnham shoots Raoul just before the latter can kill Meg and flees as police burst in with shouts of "Freeze!" and "Nobody move!" Ignoring them, Sarah rushes to Stephen, and Meg crawls out from under Raoul, moving independently of--indeed in direct disobedience of--male authority. The police arrival is almost a joke; they are too late to do anything but apprehend Burnham, who has already redeemed himself. As Meg watches his capture, the camera zooms slowly in on her face, splattered with Raoul's blood. She looks wide-eyed and remarkably young, recalling the similarly gory publicity image used for Little Girl, in which Foster's character, Rynn, also repeatedly refuses a policeman's help, her distrust of the system leading her to fend for herself. Rynn wishes to live alone after her father's death rather than become a ward of the state, but her privacy is violated 
by a pedophile, his prototypically phallic mother, and a well-meaning cop, all of whom attempt through various means to reintegrate Rynn into the social order.
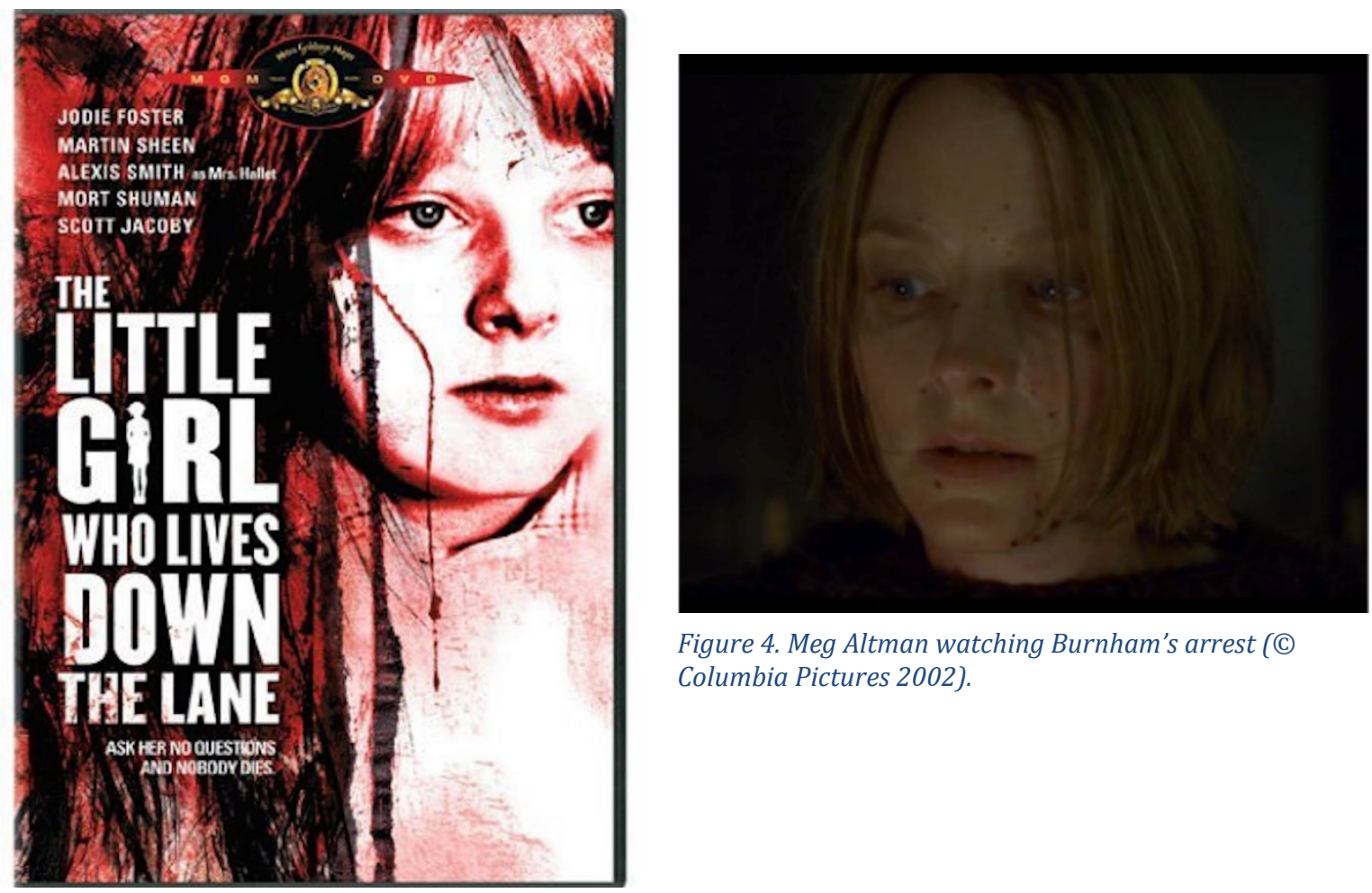

Figure 4. Meg Altman watching Burnham's arrest (C) Columbia Pictures 2002).

Figure 5. Publicity still, The Little Girl Who Lives Down the Lane (C) MGM, 1976).

Such suspicious glances at authorities abound in Foster's body of work, from Little Girl to $\underline{\text { The Accused }}$ and $\underline{\text { Silence, }}$, and post-Panic Room with $\underline{\text { Flightplan }}$ and The Brave One. If, as Freeman asserts, "identity is always in temporal drag, constituted and haunted by the failed love project that precedes it," what project constitutes and haunts Foster's star identity? ${ }^{27}$ Meg's is her defunct marriage and the loss of the trajectory she was on before marriage interrupted. For Foster, the failed love project seems to be no less than her involvement from childhood with the Hollywood industry itself, marred by omnipresent intrusive, policing gazes. Throughout her career, Foster's personal life has attracted an unusual class of attention, beyond the scope of

\footnotetext{
${ }^{27}$ Freeman, Time Binds, 93.
} 
typical celebrity fascination. From the producers of Little Girl to John Hinckley Jr. to gay activists to Foster's own brother Buddy--who published an unauthorized biography of her in 1997--to innumerable media commentators, Foster has combated invasions of privacy for decades, particularly with regard to her sexuality. ${ }^{28}$ Until 2007 she remained close-mouthed about her much-scrutinized sexual orientation and in 2013 renewed her public silence on the topic, speaking out against the imperative to speak out. ${ }^{29}$ Yet she has never been reticent about gender politics, saying in an interview with Douglas Eby, "I pride myself on knowing as much about feminism as the next person, and not being scared to say I'm a feminist." ${ }^{\prime 30}$ Hollinger describes Foster as "the only major Hollywood actress who consistently plays strong female characters and refuses to run away from the feminist label," and Richard Corliss observes that she is "maybe the only actress in Hollywood history who has built a two-decade star career without ever playing a traditional romantic lead." 31

Panic Room's final scene actualizes this commitment to feminism and chronic resistance of heteronormative gender standards across time. Rather than a conventional, touching reconciliation with Stephen, it shows Meg and Sarah outside in a park, perusing apartment listings together, no need of the hyperfeminine agent Meg let pressure her into buying the illfated brownstone. In a last biographical gesture, the film affords Foster, who graduated from Le Lycée Français de Los Angeles and does her own French-language dubbing on her films, a

\footnotetext{
${ }^{28}$ According to interviews, Foster--fourteen while filming--was traumatized by Little Girl's nude scenes and the scene in which the villain stubs his cigarette out on her pet hamster's eyes. Many gay activists who believed Silence was homophobic attacked Foster--whose sexuality was more or less an open secret at the time--for starring in it; see Michelangelo Signorile, Queer in America: Sex, the Media, and the Closets of Power (Madison: University of Wisconsin Press, 2003).

${ }^{29}$ Jodie Foster, "Jodie Foster's Golden Globes Speech: Full Transcript," ABCNews.com, 2013.

${ }^{30}$ Douglas Eby, "Jodie Foster on Making Her Film Contact--and on Filmmaking, and Gifted Women," Talent Development Resources.

${ }^{31}$ Hollinger, Pretty People, 43; and Richard Corliss, "Jodie Foster, Feminist Avenger," Time Magazine (September 14, 2007). [http://content.time.com/time/world/article/0,8599,1661951,00.html]
} 
chance to display her Gallic knowledge. Browsing the listings, Sarah asks what a concierge is, and Meg promptly answers: "It's French for superintendent." The ostensibly small detail reminds viewers one more time of the relationship between the film and its actors--not merely their characters--and between the film's actors, for Panic Room functions not only as a psychological thriller underpinned by class and gender critiques but as a transtemporal vehicle for a pedagogical and emotional relationship both lived and diegetic, a nonbiological, gender-flexible motherhood facilitated by an encounter with tomboyism and embodied female agency.

And yet a distinctive sense of unease still lingers. As Sarah describes an especially opulent rental, Meg demurs nervously, "Do we need all that space?" The imminent danger may have passed, but the structures for its recurrence remain intact: there is no real safe space in this world, and females--single and subversive ones all the more--are always under threat of patriarchal violence.

\section{Close to Home: Domesticity, Paranoia, and Feminism}

Indeed, although Foster plays mothers infrequently, maternity itself figures centrally in two thrillers on either side of Panic Room chronologically that draw just as heavily on the paranoid framework of female-centered Gothic thrillers and in which female fears are expressed, discredited, and finally validated. Many critics have noted Panic Room's Hitchcockian aspects; ${ }^{32}$ these elements link it to the domestically centered paranoid woman's films of the 1940s, which iterate what Andrea Walsh describes as "scenario[s] in which the wife invariably fears that her husband is planning to kill her. ${ }^{33}$ In Panic Room the wife's doubts about her husband's

\footnotetext{
${ }^{32}$ Among these are Swallow and Williams, as well as Mark Browning, David Fincher: Films That Scar (Santa Barbara, CA: Praeger, 2010).

${ }^{33}$ Andrea Walsh, Women's Film and Female Experience, 1940-1950 (New York: Praeger, 1984), 285.
} 
trustworthiness have already been validated, and it is the institution of Hollywood rather than marriage whose haunting by gynocide and sexual violence the film exposes.

Critical ambivalence about the midcentury cycle of paranoid domestic thrillers reflects what Diane Waldman cites as these films" "affirmation of feminine perception, interpretation, and lived experience" and, in their validation of that perception, as Walsh notes, their suggestion to "increasingly independent women that they are weaker and more vulnerable in nature than they think." ${ }^{34}$ Further, in necessitating a male figure to solve the mystery and save the woman, the female protagonist is "revealed as impotent in terms of the actual ability to uncover the secret or attain the knowledge which she desires." ${ }^{35}$ These heroines sense when something is amiss, but filmic convention precludes them from doing anything about it, and they ultimately depend on men. Yet in a host of Foster's films--her most Gothic ones, at that--men fail to come to the heroine's rescue. On the contrary, the traditional bearers of male authority in these narratives demonstrate their ineffectuality in pronounced ways: the gregarious policeman proves unable to foil a lecherous neighbor in Little Girl; an air marshal in Flightplan is revealed as the villain only after he deceives the captain into collusion; the FBI bigwig sends his agents to the wrong place in $\underline{\text { Silence }}$ while Starling bests the killer; and the police in Panic Room arrive after the action. In tandem with the male antagonists, these staged failures emphasize the all-encompassing nature of patriarchal oppression. Where Meg survives by repulsing the male gaze, Foster's oeuvre controls the gaze of chronic viewers over time on a metanarrative level, refusing to separate female characters--strong or weak--from the malignant ideological systems that produce them as subjects and precipitate their adverse situations. Through a combination of tomboyish resistance,

\footnotetext{
${ }^{34}$ Waldman, “"At Last,”" 28; Walsh, Women's Film, 193.

${ }^{35}$ Doane, Desire, 135. Qtd. in Mark Jancovich, "Crack-Up: Psychological Realism, Generic Transformation and the Demise of the Paranoid Woman's Film," Irish Journal of Gothic and Horror Studies 3 (2007).
} 
transgressive motion, and repeatedly validated anxieties about female vulnerability, Foster's films collectively repurpose cinematic violence against women across time to expose the deepseated iniquities imbricated not only in Hollywood film but also and more fundamentally within heterosexual and heterosocial relations.

The survival that Panic Room emphasizes starkly contrasts the paralysis with which Foster's other home invasion film terminates. Little Girl features another tomboy, this one orphaned, confronted with male intruders and the threat--here more explicit than in Panic Room-of sexual violence. The film opens with thirteen-year-old Rynn blowing out the candles on a cake she has made for a lonesome birthday celebration. Her father has died years earlier, and Rynn desires to remain independent rather than surrender herself into the state's custodial system. While the self-parenting child is paradigmatic in American literature from Huckleberry Finn to Katniss Everdeen, tomboy characters are isolated further, removed from peer groups as well. Although she is still a child in the juridical sense, the film constructs the orphaned Rynn as unequivocally adult: she cooks for herself, smokes cigarettes with cultivated nonchalance, listens to Chopin, and engages in sexual intercourse.

Rynn's precocity awakens a prurient interest from pedophilic neighbor Frank Hallet (Martin Sheen). Hallet is unaware that she has killed her own abusive mother in self-defense but is increasingly (and rightfully) suspicious that she has something to do with his mother's disappearance; the overbearing Mrs. Hallet (Alexis Smith) falls fatally after espying Mrs. Jacobs's corpse in the cellar. Little Girl features a curious home invasion plot in which not only a villainous criminal but also a phallic mother and a supposedly beneficent policeman repeatedly penetrate the protagonist's home unbidden, while she struggles to maintain the appearance of normality. As a representative of the law, Officer Miglioriti (Mort Shuman) symbolizes the 
"legitimate" aspect of pedophilic fascination. He professes concern for Rynn's well-being on his frequent surveillance, thereby appearing to oppose his motivations to Hallet's manifestly evil interests; the film presents the invasion of female-coded space on a ubiquitous, systemic level rather than localizing it within a few deviant individuals.

Like Panic Room, Little Girl sees Gothic convention inverted as male intruders seek access to the female protagonists' metaphorically laden hidden chambers. Little Girl's climactic scenes are occasioned by the revelation of the contents of this taboo space: not millions of dollars but dead female bodies, the reviled corpses of overly assertive women. Hallet finally corners Rynn after repeated endeavors to seduce and blackmail her when he breaks in and discovers his mother's hairpin and broken fingernail in the cellar. Outlining the conjugal visits he anticipates making to her (his wife, he assures Rynn, need never know), he delineates Rynn's appeal from the living room as she prepares tea in the kitchen: "You are brilliant. Very inventive and resourceful, very cool under fire. You know how to survive, don’t you?" Rynn meekly replies, "I thought I did," surreptitiously pouring a vial of cyanide into the teacup nearest her.

The film brings home--literally--the intransigency of the tomboy's dilemma. Although Hallet makes Rynn exchange cups with him, unwittingly condemning himself to death, her apparent victory scene is hardly triumphal. Indeed, the striking tableau of Rynn preparing tea for her would-be rapist / forcible husband combined with a prolonged close-up of her unreadable face watching Hallet die as the credits roll throws doubt on the notion that any kind of victory is attainable here at all. Perhaps, faced with imminent rape, Rynn intended to commit suicide. Perhaps, realizing the vulnerability of her situation and the need to assimilate into society for protection, she rues the exhaustion of her cyanide supply. The ambiguity with which the film surrounds this tomboy's intentions points to their very irrelevance: intent is immaterial when 
one's choices are rape, suicide, or murder. Either way means death for her--if not literal death, then the death of her resistant subjectivity and, instead, subjugation to the social order she has gone to such lengths to resist.

In Little Girl, the tomboy's quandary arises from the unpropitious circumstances in which a dead father has left his daughter, and her survival depends on the methodical destruction of the nuclear family: Rynn's refusal to allow the state to interpellate her artificially into a family, the (wo)manslaughter of her mother and Hallet's, and eventually the murder of Hallet. Yet the film ends in Rynn's paralysis, not her liberation. She refuses to surrender to her individual oppressors and remains unwilling to partake in the system that produces them, but her detachment from that social order and the bloodshed it has engendered render her now completely isolated; moreover,

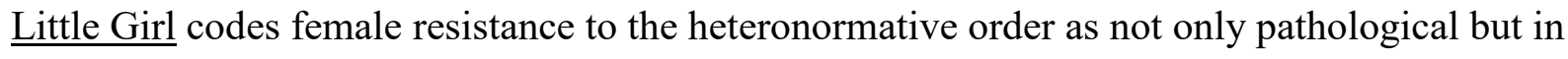
fact homicidal at its core.

The stasis in which Rynn ends presages the ills that befall so many of Foster's heroines who do struggle against that order. Corollary, perhaps, to her aforementioned "inability" to create romantic chemistry with male costars is the aforementioned proliferation of roles involving her characters being raped, assaulted, commodified, or otherwise subject to specifically gendered violence. Hollinger's point bears further attention: Foster's "inability" to play a heterosexual romantic role convincingly may be partly her own failing and partly a result of spectatorial perception/projection, but what if we assume a greater degree of intentionality on Foster's part and dispense with the presumption that she is trying or ought to try to create such chemistry? By perpetually declining to play it straight, so to speak, Foster disrupts heteronormative trajectories and expectations; her films repeatedly deromanticize and dismantle 
corresponding ideals, offering instead bare looks at the ramifications of being a nonnormative female in the US sex/gender system.

Insistent as it is upon exposing imbalances and violences inherent in heterosexual and heterosocial relationships, Foster's oeuvre, too, may register productively with chronic viewers as a manifestation of feminist paranoia, with all the term's connotations of pathology and hyperactive intellect and sexual difference. Freud's conception of female paranoia develops around a woman who suspects that the man with whom she is conducting an affair has arranged for a third party (presumed also to be male) to photograph their trysts secretly. Upon learning that the woman also believes a respected elderly female colleague knows and disapproves of the affair, Freud concludes that the woman has a pathological mother complex connected to her relationship with this coworker. The coworker thus comes to stand as the supposed agent of her persecution in her delusion and her repressed love object: the cause of pathology lies in an unhealthy bond with the mother, and its effect is the transformation of homosexual impulses into paranoia. At bottom, then, female paranoia hinges on the female bonds and desires of which hegemonic discourses--and conventional film narrative--disapprove. ${ }^{36}$

In a more recent formulation, Sianne Ngai suggests that paranoia qua "conspiracy theory" was "quietly claimed as a masculine prerogative" toward the end of the twentieth century. ${ }^{37}$ After Fredric Jameson, she characterizes (implicitly male-centered) conspiracy films as “allegories for the attempt--and, more significantly, failure . . . to grasp global capitalism's social totality in formal or representational terms" and in which protagonists "belatedly find that they are small subjects caught up in larger systems extending beyond their comprehension and

\footnotetext{
${ }^{36}$ Sigmund Freud, "A Case of Paranoia Running Counter to the Theory of the Disease," in Sexuality and the Psychology of Love (New York: Simon \& Schuster, 1963), 87-96.

${ }^{37}$ Sianne Ngai, Ugly Feelings (Cambridge, MA: Harvard University Press, 2007), 298.
} 
control." ${ }^{38}$ Ngai and Jameson view conspiracy theory as synecdochal to intellectual theory, and Ngai identifies both as primarily "male form[s] of knowledge production," insofar as universal abstractions tend to be coded as masculine. Excluded by custom from political thrillers and the domain of unmarked theory, female--more specifically, feminist--forms of abstraction (i.e., the designation of "patriarchy" as a/the definitive, totalizing system) are regarded as a "source of embarrassment" among academics. This attitude, when juxtaposed to the glorification of male abstraction / conspiracy theory highlights a fundamental imbalance, namely, that "paranoia can be denied the status of epistemology when claimed by some subjects, while valorized for precisely that status when claimed by others." ${ }^{39}$ The ability to voice and validate paranoia, therefore, to identify the systemic structures that undergird gender and genre, is integral to female resistance and the possibility of change: a paranoid reading of heterosexist paranoia.

Many feminist critics before and alongside Ngai have addressed Freud's conceptualization of paranoia in relation to film, often with respect to its characteristic symptoms of delusion, hallucination, and projection, as well as the cinematic evocations of the scenario around which Freud theorizes female paranoia. Jacqueline Rose, for example, describes the phenomenon of cinema via paranoia as "the outward projection of a rejected idea--the content of a desire--which reappears as perceived reality, against which repression manifests itself anew as opposition." ${ }^{40}$ In parallel albeit less strictly psychoanalytic terms, one might read the consistent persecution of female characters by men in Foster's oeuvre as a projection of the not-delusivebut-frequently-treated-as-such notion of an oppressive patriarchy: the paranoia Foster's body of

\footnotetext{
${ }^{38}$ Ibid., 299.

${ }^{39}$ Ibid., 302.

${ }^{40}$ Jacqueline Rose, "Paranoia and the Film System," in Feminism and Film Theory, ed. Constance Penley (New York: Routledge, 1988), 143.
} 
work performs actively calls attention to and deconstructs the systemic misogyny of cinematic narrative.

Key to this performance is a relentless iterativity equal to Hollywood's pertinaciously problematic discourses around gender deviance in daughters and mothers alike. Jyotsna Kapur outlines a recent proliferation of conspiracy thrillers that thematize the loss of children--and parental inability to care sufficiently for a child--as the "subject of horror and alarm" in such films; she contrasts this trend to the lighthearted cinematic celebrations of the "growing up of children and the growing down of adults" predominant in the 1970s and 1980s. ${ }^{41}$ Expanding on Jameson's account of the male paranoiac as a figure for the (also male) intellectual theorist who strives to apprehend the totalities of global capital, Kapur parses the gendered discrepancies between male and female paranoiac characters in film: a male paranoiac is not only “intellectually driven," as per Jameson, but an "idealized subject who thinks fast on his feet and cuts through fear to find the conspirators." The female of the species, meanwhile, "turns delusional and vulnerable to suggestions. ... [T] he character and the audience doubt her ability to think rationally." 42 For Kapur, female paranoia is intrinsically bound up with domestic concerns and woman's threatened ability to "stand as a buffer between [her] children and the market." ${ }^{43}$ These films, she asserts, submit disingenuous conceptions of political progress, merely replaying a tired "trope of diminutive white women in need of protection from outsider threats" that perpetuates sexist and racist ideologies.

Yet to dismiss such films on the basis of their putative individualization of misogyny forecloses the possibility of allegorical and cumulative readings that would provide precisely the

\footnotetext{
${ }^{41}$ Jyotsna Kapur, "Fear on the Footsteps of Comedy: Childhood and Paranoia in Contemporary American Cinema," Visual Anthropology 22 (2009): 44.

${ }^{42}$ Ibid.

${ }^{43}$ Ibid., 47-48.
} 
"more systemic understanding" for which Kapur calls. ${ }^{44}$ In Foster's case, this understanding entails presenting unremittingly misogynistic climates in which inurement breeds disavowal. Dispersed across her corpus, her thrillers drag along key elements of their generic predecessors and the anxieties over increasing female independence they reflect according to their respective historical contexts: Little Girl Cold War concerns about the dissolution of the nuclear family and the sexualization of adolescents in film and culture, for example, and Flightplan the (often manufactured) threat of international terrorism and its obfuscation of less sensational domestic threats. By insistently posing problematized depictions of the heteronormative nuclear family and heterosexuality more broadly, Foster has literally acted out a mode of feminist paranoia over the past forty-odd years, theorizing the "holistic and all-encompassing structure" to which the abstractions of both patriarchy and the less "embarrassing" heteronormativity apply. ${ }^{45}$

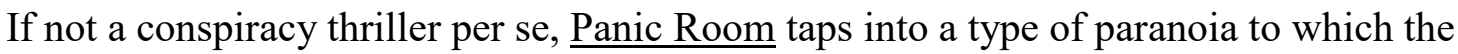
female body is conditioned, paranoia that sees home invasion as allegorical of rape and rape as symptomatic of the systemic structure feminists are derisively termed "paranoid" for calling patriarchy. As the preceding discussion of Panic Room indicates, films that center on a female character and her (violated) rights as a mother, as well as threats to her bodily integrity, are necessarily political and do offer systemic understandings of heteronormative ideology. Just as the personal is political, the domestic thriller is a political thriller, albeit a kind in which the female subject's knowledge production is circumscribed and individualized to home and family-but no less allegorical of a holistic and all-encompassing system.

Forty years after Little Girl, Flightplan addresses these very relations among domesticity, paranoia, conspiracy, and gender, confronting its female lead with a political conspiracy to

\footnotetext{
${ }^{44}$ Ibid., 50.

45 "Holistic" quote from Ngai, Feelings, 299.
} 
which--due to a perceived state of hysteria ostensibly brought on by her husband's death-nobody onboard gives credence. A more conventional conspiracy thriller than Panic Room, it stars Foster as Kyle Pratt in a role originally written for Sean Penn; the film might be termed "political" insofar as it involves terrorist plots, international collusion, and federal agents in a post-9/11 milieu saturated with and structured by fear, yet for Kyle, the issue at hand is still domestic: her daughter, Julia (Marlene Lawston), disappears from an airborne plane, and nobody else admits to having noticed her. Finally dismissed by the crew and passengers as delusional, Kyle insists precisely that something is wrong with the system. She is right, of course; Air Marshal Carson (Peter Sarsgaard) and a female flight attendant are part of a terrorist plot to hijack the plane and frame her. After the repeated disturbances she causes force an emergency landing, Kyle manages to escape from the villainous coconspirators, find Julia, and detonate the planted explosives. On one level, Flightplan consolidates Ngai's and Kapur's notions of female conspiracy theory and paranoia confined to the context of motherhood, but a consideration of it within the larger context of Foster's career, and particularly the groundwork Panic Room's queer reproductivity lays, offers insight into the very trope that concerns them rather than simply reiterating it.

As generic convention precludes any real spectatorial doubt as to Kyle's sanity, the film's real interest lies in the ways this heroine is silenced, that is, how misogynistic gender norms are deployed to discredit and disempower her. The system the villains have installed is comprehensive, transnational, and predicated chiefly on cultural assumptions about gender. They have tampered with the flight information, prevented anyone from seeing Julia, and conspired with the Berlin hospital to convince everyone that Kyle's daughter died along with her husband, resulting in Kyle's psychological instability. Kyle finds herself beset by traditionally 
authoritative masculinity and its feminine accessory in Stephanie (Katie Beahan), the catty flight attendant. By constantly invoking the feminizing rhetoric of mental illness--delusion, hysteria, hallucination--the villains persuade the ostentatiously fair-minded captain first that Kyle's excessive emotionality is a danger to everyone onboard and later that she is in fact hatching a terrorist plot and has rigged the plane with explosives. He finds Carson's conspiracy theory much easier to swallow than Kyle's, never questioning Carson's governmentally endorsed authority. Disenfranchised by dominant tropes of female irrationality, Kyle has no way to make herself heard within the bounds of socially and legally acceptable discourse. She escapes Carson's surveillance by climbing through the latrine ceiling and into the plane's infrastructure, and when the plane lands, she finally locates a drugged Julia and shields herself and her daughter inside a protected compartment as she detonates the explosives. The girl and the film's answer, fittingly, are hidden in avionics--the section of an airplane that enables navigation, communication, displays, and the hundreds of other electrical systems necessary to proper function: the infrastructure, where, as Ngai and Kapur suggest, only someone asking, knowing how to ask, and willing to cause immense trouble might find them. Flightplan does not circumscribe Kyle's maternal protectiveness to tropes of fierce motherhood and heterosexual reproduction but links it to female resistance and questions of feminist epistemology. Julia must be saved, per this view, so that she might learn from Kyle to ask the right questions, analyze systems, and interrogate infrastructures: something is wrong indeed, and its redress necessitates female transgression on multiple levels. At the same time, Julia is an aptly gendered device through which to stage this film's disquisition on female paranoia and the validity of Foster's acted anxieties about systemic violence against women, lived and narrativized alike. The relationship between mother and daughter proves paramount, as in Panic Room, but again in a 
way that prioritizes the mother rather than abnegating her. Vindication comes not in the child's salvation but in the affirming female homosociality that her realized existence allows: the film's outcome is not "for the child" but for the mother, validating her claims and legitimating her paranoia.

\section{Conclusions: Foster Parenting}

This mode of feminist reproduction that Flightplan and Panic Room posit does not correspond to the hierarchal descendence of the biological nuclear family. Indeed, in the years following the completion of both films, Foster herself has enacted one such mode of feminist homosociality and inheritance that exceeds biological ties. Alongside the gendered problematics of past and present her oeuvre exposes, the future of sustained female cooperation against heteronormative forces that Panic Room creates has proven beneficial to both the characters and actresses alike. Through her relationship with Foster, Kristen Stewart has gained a parental surrogate to help her endure real-life invasions by an ever-surveillant public--and Foster has been active in that role. Now taking cues, perhaps, from her own experience with motherhood, as well as Meg's metamorphosed maternity, Foster continues to enact an oblique, mimetically reproductive connection with Stewart. In doing so, she is also, to reinvoke Freeman, being a drag--that is, issuing an ethical injunction to the public's collective conscience: in 2012, when Stewart herself was dragged in a different sense--through the mud--for her affair with $\underline{\text { Snow }}$ White and the Huntsman (2012) director Rupert Sanders, Foster authored an impassioned defense of Stewart and child actors in general in the Daily Beast, contending that "we seldom consider the childhoods we destroy ... the online harassment ... humiliations ... when the public throws stones." Further, she writes, "If I were a young actor today I would quit before I 
started. . . I don't think I could survive [this mediated culture] emotionally."46 The emotional hardships to which Foster alludes entail the loss of the relative freedoms and mobilities that characterize tomboyism as a resistant mode of gender; Stewart's treatment and putative devolution from tomboy to "trampire" exemplify the effects of the public's disciplinary gaze upon the (now) feminine subject whose existence it both impels and abhors. ${ }^{47}$ The relative license she had to transgress gender norms as a child has disappeared and been replaced by the stringent correctives of acceptable feminine sexuality. ${ }^{48}$

Viewed retrospectively, Panic Room offers one possible reparative to such predicaments for Stewart, Foster, their characters, and mothers and children within and outside of Hollywood. Through its reversal of the tomboy-taming trope and its renunciation of chrononormative character development, the film makes available modes of defeminized motherhood and enduring tomboyism that exceed the bounds of the narrative, reaching into past, present, and future to foster more salutary encounters between females and the passage of time.

Patriarchy sees a danger in tomboys, and their treatment in popular narrative reflects this masculinist paranoia--the fear that rebellious females left unrehabilitated into society could overturn the male-dominated social order. It regards them as threats to its supremacy and

\footnotetext{
${ }^{46}$ Jodie Foster, "Jodie Foster Blasts Kristen Stewart-Robert Pattinson Break-Up Spectacle," Daily Beast, August 15, 2012.

${ }^{47}$ Actor-comedian Will Ferrell coined the term "trampire" in a 2012 interview with Conan O'Brien; it refers to Stewart's vampiric role in the Twilight as Robert Pattinson's love interest and on the set of which the two began dating.

${ }^{48}$ It bears noting, albeit on strictly speculative levels, that throughout the time of this essay's revision, Kristen Stewart's purported romance with her assistant Alicia Cargile has been a source of much fan and media speculation; though Stewart herself has never publicly identified as queer, an interview surfaced in which her mother, Jules, spoke out in support of this relationship--but that interview was later decried as false. Compellingly, moreover, Stewart's recent role in The Clouds of Sils Maria (Olivier Assayas, 2014) casts her as assistant and implicit love interest to Juliette Binoche's actress character. See Rachel Mcrady and Alli Rosenbloom, "Kristen Stewart's Mom Jules Denies Story: I Never Spoke about Her Love Life!," Us Weekly, 15 June 2015.
} 
therefore mandates their "expiration." The paranoid temporality to which Foster's body of work gives life, rife as it is with resistant female characters, is not so much the suspicious simultaneity that Ngai ascribes to the individualized conspiracy thriller but the systemic and virulent chronicity with which females in heterosexual and heterosocial relations are disadvantaged. The female homosociality that Panic Room presents, that Little Girl denies, and that Flightplan restores matters because it politicizes the tomboy in specific relation--a relation that mainstream narrative typically occludes--to feminist concerns about the sovereignty of females over their own bodies. It deisolates the tomboy and grants her a (re)generative power, proliferating resistance and underscoring the need for that resistance; indeed, it points to the potency of filmic tomboys and tomboy narratives more generally as much-needed objects for future queer and feminist inquiry.

\title{
Acknowledgments
}

I am most grateful to all those who offered input on this article in its various incarnations, especially Adin Lears, Lucinda Ramberg, Masha Raskolnikov, Camille Robcis, Nick Salvato, Amy Villarejo, Sara Warner, Dagmawi Woubshet, and the anonymous readers for the Velvet Light Trap. Many thanks, too, to all who have indulged me over the years in conversations academic and otherwise about Jodie Foster and her films.

\begin{abstract}
About the Author
Lynne Stahl earned her PhD in English from Cornell University in May 2015. Her dissertation explores the ways in which cultural conceptions of gender, sexuality, and emotion inform filmic tomboy narrative, and vice versa.
\end{abstract}

